\title{
Minority Stress and Health: Implications for Lesbian, Gay, Bisexual, Transgender, and Questioning (LGBTQ) Young People
}

Cathy Kelleher

Technological University Dublin, cathy.kelleher@tudublin.ie

Follow this and additional works at: https://arrow.tudublin.ie/aaschsslarts

Part of the Clinical Psychology Commons, and the Mental and Social Health Commons

\section{Recommended Citation}

Kelleher, C. (2009). Minority stress and health: Implications for lesbian, gay, bisexual, transgender, and questioning (LGBTQ) young people. Counselling Psychology Quarterly, 22:4, 373-379. doi:10.1080/ 09515070903334995.

This Article is brought to you for free and open access by the Social Sciences at ARROW@TU Dublin. It has been accepted for inclusion in Articles by an authorized administrator of ARROW@TU Dublin. For more information, please contact arrow.admin@tudublin.ie, aisling.coyne@tudublin.ie,gerard.connolly@tudublin.ie.

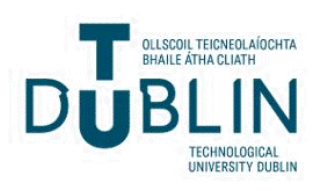




\title{
Minority Stress and Health: Implications for Lesbian, Gay, Bisexual, Transgender, and Questioning (LGBTQ) Young People
}

\author{
Cathy Kelleher \\ Dublin Institute of Technology
}

Correspondence may be addressed to: Department of Social Sciences, Dublin Institute of Technology, 41-45 Mountjoy Square, Dublin 1, Ireland. Telephone: 00353 (0) 14024265. Email: cathy.kelleher@dit.ie. 


\section{Minority Stress and Health: Implications for Lesbian, Gay, Bisexual, Transgender, and Questioning (LGBTQ) Young People}

Cathy Kelleher*

Department of Social Sciences, Dublin Institute of Technology

(Received $21^{\text {st }}$ February 2008)

\section{Abstract}

Historically, the pathologisation of LGBTQ orientations shaped research and professional practice, while the impact of stigma was not considered. Within a minority stress conceptualisation however, stigma-related prejudice and discrimination experienced by LGBTQ people constitute chronically stressful events that can lead to negative health outcomes. Minority stress has been linked to psychological distress among gay men and lesbians and may contribute to elevated rates of distress frequently observed among LGBTQ youth. This study explored the impact of minority stress on psychological distress among LGBTQ youth in Ireland. Measures assessing three components of minority stress (sexual identity distress, stigma consciousness, and heterosexist experiences) were administered online to LGBTQ youth aged 16-24 years $(\mathrm{N}=301)$. Each minority stressor had a significant independent association with distress. Stepwise regression analyses identified the linear combination of minority stressors as significantly predictive of distress $[\mathrm{F}(3,201)=30.80, \mathrm{P}=<$ .001]. Results suggest that the oppressive social environment created through sexual/transgender identity-related stigma negatively impacts on the well-being of LGBTQ youth. Findings have implications for health professionals and policy makers interested in the concerns of LGBTQ youth experiencing difficulties related to minority status and will facilitate the development and tailoring of interventions aimed at reaching those most at risk. Keywords: minority stress; lesbian, gay, bisexual, transgender youth; psychological distress; online survey 
*Email: cathy.kelleher@dit.ie 


\section{Minority Stress and Health: Implications for Lesbian, Gay, Bisexual, Transgender, and Questioning (LGBTQ) Young People}

\section{Introduction}

International research demonstrates that experiences of stigma-related prejudice, discrimination and victimisation frequently characterise the lives of lesbian, gay, bisexual, and transgender (LGBT) individuals (e.g. Balsam, Beauchaine \& Rothblum, 2005; Huebner, Rebchook \& Kegeles, 2004). Such experiences have been linked to a range of negative outcomes including psychological distress (e.g. Smith \& Ingram, 2004; Szymanski, 2005). Research has demonstrated high rates of suicidality among LGBT populations in the United Kingdom (e.g. McNamee, 2006) and has linked suicidality to negative experiences resulting from stigmatisation (Johnson, Faulkner, Jones \& Welsh, 2007). Although LGBT identities are becoming more visible in Ireland, they remain stigmatised and must develop within a heterosexist environment; one that dictates heterosexual normativity and expects gender conformity. Little empirical research has addressed the experiences of LGBT people in Ireland, however there have been a number of recent calls for urgent research to understand the lives of this marginalised group.

LGBT young people are especially vulnerable, with many experiencing harassment and victimisation in school, home, work and community settings (e.g., Pilkington \& D'Augelli, 1995; Rivers, 2001). High rates of psychological distress are frequently observed among LGBT youth (e.g., D 'Augelli, 2002) and lesbian, gay, and bisexual (LGB) adolescents are more likely to attempt and complete suicide than heterosexual adolescents (Russell \& Joyner, 2001). While elevated levels of distress and suicidality were once believed to result directly 
from an LGBT identity, it is now increasingly understood that such difficulties are associated with the adverse social conditions that these youth frequently experience as a result of the stigma that society attaches to their identities.

One theoretical framework that has been used to understand the impact of stigma on LGB persons is the minority stress model which proposes that stigma, prejudice and discrimination constitute unique, chronic, psychosocial stressors that can lead to negative health outcomes (Meyer, 2003). In one study, gay men who experienced high levels of minority stress were two to three times more likely to experience high levels of psychological distress (Meyer, 1995). Among LGB youth, research indicates that stigma-related harassment, discrimination and victimisation can result in increased mental health symptoms and suicidality (e.g. Huebner, Rebchook \& Kegeles, 2004).

The little research undertaken in Ireland indicates that gay men and lesbians experience prejudice and discrimination in many areas impacting health, and that many experience distress (e.g. GLEN/Nexus, 1995; Equality Authority, 2007). Young gay men and lesbians face problems of homophobic bullying (e.g. Minton, Dahl, O’Moore \& Tuck, 2006) and harassment, depression and low self-esteem in the education system (GLEN/Nexus, 1995; Gay HIV Strategies/Nexus, 2000). There is increasing concern regarding suicidality among LGBT youth in Ireland, with reports that one-in-five LGB young people have attempted suicide (Heffernan, 2007). The available evidence clearly indicates the need to understand how socially-induced stressful conditions impact on psychological distress and suicidality for LGBTQ individuals in Ireland, and particularly for young people who are especially at risk. 


\section{Participants}

The sample consisted of 301 self-identified LGBTQ youth aged 16-24 years, who were residing in the Republic of Ireland. Respondents had a mean age of 20.78 (sd 2.486) years, and identified their sexual identity as lesbian (15\%), gay (55\%), bisexual (19\%), questioning (9\%), heterosexual (1\%) and 'other' (1\%), and their gender identity as female (25\%), male $(69 \%)$, transgender (3\%), and questioning (3\%). Participants were recruited via a recruitment advertisement placed on community resource websites and linked to an online survey, which was available for 12 weeks.

\section{Questionnaire}

The questionnaire measured minority stressors: actual experiences of sexual/transgender identity-related prejudice and discrimination (heterosexist experiences); expectations for rejection (stigma consciousness); and internalisation of society's negative attitudes (sexual/gender identity distress); and also psychological distress. The instruments used were modified with authors' permission.*

- *The Workplace Heterosexist Experiences Questionnaire (Waldo, 1999)

(The author was not contactable) 
- The Stigma Consciousness Questionnaire (Pinel, 1999)

- The Sexual Identity Distress Scale (Wright \& Perry, 2006)

- The Mental Health Inventory Psychological Distress I Subscale (Veit \& Ware, 1983)

The questionnaire also collected demographic information and data on respondents' level of openness about sexual/gender identity, support network, and participation in the LGBT community.

\section{Analysis}

Regression analyses were employed to determine the impact of each minority stressor on psychological distress and also to establish the combined effect of minority stress on psychological distress.

\section{Results}

Table I presents bivariate correlations and descriptive statistics for each subscale. Bivariate associations demonstrated a significant association of each minority stressor, (heterosexist experiences, stigma consciousness, and sexual identity distress) and psychological distress (anxiety, depression, and suicide ideation). 
INSERT TABLE I ABOUT HERE

Multiple regression analyses confirmed bivariate associations and demonstrated that each minority stressor retained its significant association with psychological distress after control for possible confounding variables (Table II). Stepwise multiple regression analysis examined the combined effects of the minority stressors on psychological distress. The linear combination of the three minority stressors was significantly predictive of psychological distress $[\mathrm{F}(3,201)=30.80, \mathrm{P}=<.001]$, accounting for $31.5 \%$ of the variance (Table II). The effect size for the model is .56.

INSERT TABLE II ABOUT HERE

\section{Discussion}

The study aimed to investigate the impact of minority stress on psychological distress among LGBTQ youth in Ireland. Findings are consistent with previous research that demonstrates an association between minority stress and psychological distress (e.g. Meyer, 1995). Minority stressors were shown to significantly predict negative psychological outcomes among the young people studied.

Actual experiences of heterosexism were the strongest individual predictor of distress among the young people. Such experiences, ranging from hearing an anti-gay joke to being physically hurt, represent severe and chronic societal stressors in the lives of LGBTQ people. 
Such stressors render the environment hostile and unpredictable and may thus increase feelings of vulnerability (Meyer, 2003) and self doubt (Garnets, Herek \& Levy, 1992) resulting in psychological distress.

Results indicate that the greater the young person's expectation for rejection based on their sexual/gender identity, the more likely they are to report symptoms of anxiety, depression, and suicide ideation. These findings are consistent with findings of Lewis, Derlega, Griffin and Krowinski (2003) that perceived stigma is positively associated with symptoms of depression among gay men and lesbians. Experiences of prejudice and discrimination may reinforce expectations for rejection that the young person may develop as a result of heterosexism. The young person may feel the need to conceal their identity to avoid negative sanctions, and to remain constantly alert. This may result in considerable distress.

Consistent with Wright and Perry (2006), sexual identity distress was significantly predictive of psychological distress. LGBT young people develop with an awareness of society's negative regard for all that is not heterosexual or gender conforming and may apply society's negative attitudes to themselves, resulting in negative self-regard (Gonsiorek, 1993) and emotional distress.

The three stressors in combination were the strongest predictor of psychological distress and so young people experiencing high levels of the three minority stressors reported more symptoms of psychological distress. Findings demonstrate that heterosexism is significantly related to feelings of distress and suicidality among LGBTQ youth in Ireland, and in doing so shift focus from a deficit-model on to how the oppressive, stigmatising social environment 
can have adverse health effects for LGBTQ youth. Although the cross-sectional design of the study and convenience sampling limit the extent to which the results can be generalised, the indication is that distress among LGBTQ youth stems from cultural ideologies that devalue all that is not heterosexual and gender conforming. In addition, while levels of distress observed among LGBTQ youth may often be higher than those observed among heterosexual youth, for many they are not likely to be clinically significant. However, LGBTQ youth do experience distress resulting from stigmatisation and this must be addressed in order to enhance wellbeing and to avoid the development of future difficulties.

\section{Conclusion and Implications}

The current study addressed the link between sexual/transgender identity and psychological distress among LGBTQ youth in Ireland. Clearly it is necessary to identify socially induced stressful conditions and to further understand their negative impact on LGBTQ youth. Attention needs to be focused on changing the oppressive cultural context in which LGBTQ youth live and so interventions need to address challenging heterosexism at both the cultural and individual level and to promote social change toward an inclusive society. The knowledge created through this research can contribute to the development programmes aimed at ameliorating the effects of stigma and heterosexism.

In addition to challenging heterosexism, appropriate support for young LGBTQ people in Ireland must be developed. While attitudes to LGBTQ identities appear to be improving, identifying as LGBTQ remains highly stigmatising and often elicits negative reactions. 
However, many young LGBTQ persons cope effectively with stigma. This highlights the resiliency of LGBT youth and emphasises the need to fully understand the complex processes in operation. The minority stress framework recognises the power of the individual to respond to adverse conditions. Clearly, further research, education and training are required. Guidelines for therapy with LGB clients (American Psychological Association, 2000) emphasise the need to understand how stigma impacts LGB individuals. Such understanding will give practical direction to those interested in the concerns of young LGBTQ persons and will facilitate the development and tailoring of interventions aimed at reaching those most at risk.

\section{Acknowledgements}

The author would like to thank all the young people who participated in the study, the many organisations that collaborated in the research and Dr Katie Baird for her invaluable contributions. 


\section{REFERENCES}

AMERICAN PSYCHOLOGICAL ASSOCIATION (2000). Guidelines for psychotherapy with lesbian, gay, and bisexual clients. American Psychologist, 55(12), 1140-1451.

BALSAM, K.F., BEAUCHAINE, T.P. \& ROTHBLUM, E.D. (2005). Victimisation over the life span: A comparison of lesbian, gay, bisexual, and heterosexual siblings. Journal of Consulting and Clinical Psychology, 73(3), 477-487.

D'AUGELLI, A.R. (2002). Mental health problems among lesbian, gay, and bisexual youths ages 14-21. Clinical Child Psychology and Psychiatry, 7(3), 433-456.

EQUALITY AUTHORITY, (2007). Recognising LGB Sexual Identities in Health Services. Dublin: Equality Authority.

GARNETS, L.D., HEREK, G.M. \& LEVY, B. (1992). Violence and victimisation of lesbians and gay men: Mental health consequences. In G.M. HEREK \& K.Y. BERRILL (Eds.), Hate crimes: Confronting violence against lesbians and gay men (pp. 207-226). Newbury Park, CA: Sage.

GAY HIV STRATEGIES/NEXUS RESEARCH (2000). Education: Lesbian and Gay Students. Dublin: Gay HIV Strategies/Nexus Research. 
GLEN/NEXUS (GAY AND LESBIAN EQUALITY NETWORK AND NEXUS RESEARCH CO-OPERATIVE) (1995). Poverty - Lesbians and Gay Men: The Economic and Social Effects of Discrimination. Dublin: Combat Poverty Agency.

GONSIOREK, J.C. (1993). Mental health issues of gay and lesbian adolescents. In L.D. GARNETS \& D.C. KIMMEL (Eds.), Psychological perspectives on lesbian and gay male experiences. New York: Columbia University Press.

HEFFERNAN, B. (2007, 5 March). One-in-five gay and lesbian youths attempted suicide. The Irish Independent. Retrieved February 18, from www.independent.ie/nationalnews/oneinfive-gay-and-lesbian-youths-attempted-suicide-48054.html.

HUEBNER, D.M., REBCHOOK, G.M. \& KEGELES, S.M. (2004). Experiences of harassment, discrimination and physical violence among young gay and bisexual men. American Journal of Public Health, 94, (7), 1200-1203.

JOHNSON, K., FAULKNER, P., JONES, H. \& WELSH, E. (2007). Understanding Suicide and Promoting Survival in LGBT Communities. Brighton: Brighton \& Sussex Community Knowledge Exchange Project.

LEWIS, R.L., DERLEGA, V.J., GRIFFIN, J.L. \& KROWINSKI, A.C. (2003). Stressors for gay men and lesbians: Life stress, gay-related stress, stigma consciousness, and depressive symptoms. Journal of Social and Clinical Psychology, 22(6), 716-729. 
MCNAMEE, H. (2006). Out on Your Own: An Examination of the Mental Health of Young Same-Sex Attracted Men. Belfast: The Rainbow Project.

MEYER, I.H. (1995). Minority stress and mental health in gay men. Journal of Health and Social Behaviour, 7, 9-25.

MEYER, I.H. (2003). Prejudice, social stress and mental health in lesbian, gay and bisexual populations: Conceptual issues and research evidence. Psychological Bulletin, 129, (5), 674-697.

MINTON, S.J., DAHL, T., O’MOORE, A.M. \& TUCK, D. (2006). Exploratory Survey of the Experiences of Homophobic Bullying amongst LGBT Young People in the Republic of Ireland. Dublin: Trinity College.

PILKINGTON, N.W. \& D’AUGELLI, A.R. (1995). Victimization of Lesbian, Gay, and Bisexual Youth in Community Settings. Journal of Community Psychology, 23, 3456.

PINEL, E.C. (1999). Stigma consciousness: the legacy of social stereotypes. Journal of Personality and Social Psychology, 76(1), 114-128. 
RIVERS, I. (2001). The bullying of sexual minorities at school: Its nature and long-term correlates. Educational and Child Psychology, 18 (1), 33-46.

RUSSELL, S. T. \& JOYNER, K. (2001). Adolescent sexual orientation and suicide risk: Evidence from a national study. American Journal of Public Health, 91, 1276-1981.

SMITH, N.G. \& INGRAM, K. (2004). Workplace heterosexism and adjustment among lesbian, gay and bisexual individuals: The role of unsupportive social interactions. Journal of Counseling Psychology, 51(1), 57-67.

SZYMANSKI, D.M. (2005). Heterosexism and sexism as correlates of psychological distress in lesbians. Journal of Counseling and Development, 83(3), 355-360.

VEIT, C. \& WARE, J. (1983). The structure of psychological distress and well-being in general populations. Journal of Consulting and Clinical Psychology, 51, 730-742.

WALDO, C.R. (1999). Working in a majority context: A structural model of heterosexism as minority stress in the workplace. Journal of Counseling Psychology, 46, 218-232.

WRIGHT, E.R. \& PERRY, B.L. (2006). Sexual identity distress, social support, and the health of gay, lesbian, and bisexual youth. Journal of Homosexuality, 51(1), 81-109. 
Table I. Bivariate Correlations and Descriptive Statistics for Each Scale

\begin{tabular}{lllll}
\hline Variable & SC & SID & HE & PD \\
\hline & & & & \\
Stigma Consciousness (SC) & 1 & & & \\
Sexual Identity Distress (SID) & $.342^{* *}$ & 1 & & \\
Heterosexist Experiences (HE) & $.560 * *$ & $.318 * *$ & 1 & \\
Psychological Distress (PD) & $.412 * *$ & $.350 * *$ & $.485 * *$ & 1 \\
No. of Scale Items & 10 & 7 & 22 & 22 \\
Possible Scale Range & $0-60$ & $7-35$ & $0-88$ & $22-132$ \\
Participant Scale Range & $6-54$ & $7-35$ & $0-87$ & $23-129$ \\
Scale Mean & 30.41 & 16.32 & 22.96 & 61.16 \\
Scale Standard Deviation & 9.91 & 6.63 & 16.58 & 23.06 \\
\hline
\end{tabular}

$* * \mathbf{p}<.01$

Table II. Psychological Distress Predicted by Each Minority Stress Variable with Possible Confounding Variables and by the Three Minority Stress Variables Combined with Control Variables

Dependent Variable

Psychological Distress

\section{$\mathbf{N}$}

$\mathbf{R}^{2}$

Stigma Consciousness (SC)

Sexual Identity Distress (SID)

Heterosexist Experiences (HE)

\begin{tabular}{lccc} 
& \multicolumn{2}{l}{ Psychological Distress } & Combined \\
\cline { 2 - 3 } SC & SID & HE & 205 \\
\hline 203 & 206 & 202 & .315 \\
.234 & .218 & .296 & .35
\end{tabular}

$* \mathbf{p}<.05 ; * * \mathbf{p}<.01 ; * * * \mathbf{p}<.001$ 